\title{
Health, Wealth and Inequality: a Contribution to the Debate about the Relationship between Inequality and Health
}

\author{
SCOTT ALAN CARSON \\ CESIFO WORKING PAPER No. 2256 \\ CATEgory 3: Social Protection \\ MARCH 2008 \\ An electronic version of the paper may be downloaded \\ - from the SSRN website: \\ wWw.SSRN.com \\ - from the RePEc website: \\ - from the CESifo website: \\ www.RePEc.org \\ www.CESifo-group.org/wp
}




\title{
Health, Wealth and Inequality: a Contribution to the Debate about the Relationship between Inequality and Health
}

\begin{abstract}
The relationship between material inequality and health is the subject of considerable debate, and may depend on how the relationship is defined. This paper uses stature as its measure for cumulative health outcomes to illustrate that the 19th century relationship between material inequality and health was negative; greater average state wealth was associated with taller individual statures. The paper also proposes and supports a bio-spatial relationship between the environment and stature.
\end{abstract}

JEL Code: I12, I31, I32.

\author{
Scott Alan Carson \\ School of Business \\ University of Texas, Permian Basin \\ 4901 East University \\ Odessa, TX 79762 \\ USA \\ carson_s@utpb.edu
}

Please do not cite without permission from the author.

I appreciate comments from participants from Marco Sünder and John Komlos were particularly helpful. Owen Wallace-Servera, Sandy Triepke and Anita Voorhies provided excellent research assistance. All errors are mine. 
Health, Wealth and Inequality: a Contribution to the Debate about the relationship between Inequality and Health

\section{Introduction}

A lively debate regarding the relationship between material inequality and modern health outcomes has arisen between social scientists on the one hand who maintain that inequality has deleterious affects on human health (Wilkinson, 1996; Wilkinson and Pickett, 2006; Lynch et al, 1998), and those on the other who maintain the relationship is largely a statistical artifact (Deaton, 2002, p. 115; Gravelle, 1998). The causal mechanism appears clear. Greater relative inequality forecloses those at the lower end of the socioeconomic strata from medical care, nutrition and health intervention, which reduces morbidity and increases longevity. However, medical intervention to extend life is a recent phenomenon. Until the mid $-20^{\text {th }}$ century, medical intervention played a minor role in increasing longevity; the majority of life expectancy increases came from improved nutrition, and overcoming infectious and sanitation diseases (Cutler, 2004, p. 2). Therefore, while not diminishing the importance of modern medical technology, the greatest life expectancy increases and improved health outcomes were the result of better nutrition and improved sanitation conditions.

There are several methods to model health outcomes. Life expectancy reflects both the current and cumulative health environment, and stature measures the net cumulative difference between nutrition, environmental conditions, disease insults and 
calorie claims for work (Eveleth and Tanner 1966; Steckel, 1979 and 1995). When diets, or the physical environments improve, average stature increases and decreases when diets become less nutritious, disease environments deteriorate or the physical environment places more stress on the body. Stature also contributes to the debate regarding the link between inequality and health. For example, much of the modern debate about the relationship between inequality and health addresses current income inequality and current mortality, which are also related to race. However, wealth is a net cumulative measure for material welfare, and stature is a net cumulative measure for biological welfare and the interaction between stature and wealth may be a neglected relationship between inequality and health outcomes.

It is against this backdrop that this paper introduces large new $19^{\text {th }}$ century anthropometric and material wealth data sources to consider the relationship between stature, wealth, inequality, and the physical environment. Two questions are considered. First, what was the historical relationship between a state's wealth distribution, its average wealth and individual stature? If social scientists who maintain that inequality has deleterious effects on human health are correct, individual stature in states with greater inequality will be shorter and statures in low inequality states will be taller. If, however, social scientists who maintain that the relationship between health and inequality is primarily a statistical artifact are correct, there will be little or no relationship between individual stature and wealth inequality. Regardless of how inequality was associated with stature, a positive relationship is expected between individual stature and average county wealth (Steckel, 1983, 1995). Second, this paper proposes a new biological-geographical hypothesis (insolation or direct sunlight) to 
explain, in part, why whites were taller than blacks, why Southerners were taller than Northerners and why farmers were consistently taller than non-farmers (Steckel, 1979; Margo and Steckel, 1982; Komlos, 1992; Komlos and Coclanis, 1997; Bodenhorn, 1999; Sünder, 2004). Consequences of omitting some of these key variables is also considered.

II. Nineteenth Century US Prison, Wealth and Demographic Data

To test the relationship between stature, wealth, inequality, and the geographic environment, four data sets are constructed: $19^{\text {th }}$ century US prison data, $19^{\text {th }}$ century US state-level average wealth and gini coefficients, a modern state-level solar radiation index, and state population densities from the 1860 and 1870 US censuses.

\section{Prison Data}

The height data used here to assess the relationship between health and inequality is a subset of a much larger $19^{\text {th }}$ century prison sample. All state prison repositories were contacted and available records were acquired and entered into a master data set. These prison records include Arizona, California, Colorado, Idaho, Illinois, Kansas, Kentucky, Missouri, Ohio, Oregon, Pennsylvania, and Texas (Table 1). Between 1830 and 1920, prison guards routinely recorded the dates inmates were received, age, complexion, nativity, stature, pre-incarceration occupation and crime. To take advantage of 1860 and 1870 census wealth and inequality data, the prison data used here are restricted to birth between 1859 to 1861 and 1869 to 1871, and only blacks and whites are considered. Fortunately, inmate enumerators were quite thorough when recording inmate complexion and occupation. For example, enumerators recorded inmates' race in a complexion category. African-Americans were recorded as black, light-black, dark-black and various shades of mulatto (Komlos and Coclanis, 1997). Whites were recorded as light, 
medium, dark, fair and white. This white race scheme is further supported by European inmates, who were also recorded as light, medium, dark, fair and white. ${ }^{1}$

Table 1, Nineteenth Century US Prison Sample

\begin{tabular}{l|cclcc}
\hline Prison & Number & Percent & & Number & Percent \\
\hline Arizona & 32 & .29 & Kentucky & 738 & 6.75 \\
California & 615 & 5.62 & Missouri & 1,436 & 13.13 \\
Colorado & 28 & .26 & Ohio & 2,333 & 21.34 \\
Idaho & 3 & .03 & Oregon & 94 & .77 \\
Illinois & 417 & 3.81 & Pennsylvania & 1,704 & 15.28 \\
\hline Kansas & 77 & .70 & Texas & 3,468 & 31.71 \\
\hline
\end{tabular}

Source: Data used to study black and white anthropometrics is a subset of a much larger $19^{\text {th }}$ century prison sample. All available records from American state repositories have been acquired and entered into a master file. These records include Arizona, California, Colorado, Idaho, Illinois, Kansas, Kentucky, Missouri, New Mexico, Ohio, Oregon, Pennsylvania, Texas, Utah and Washington.

All historical data have various biases, and there is always concern over entry requirements, be it to prison or the military. Physical descriptions were recorded by prison enumerators at the time of incarceration as a means of identification. One common shortfall of military samples is a truncation bias imposed by minimum stature requirements (Fogel et al, 1978, p. 85; Sokoloff and Villaflor, 1982, pp. 459 and 472). Fortunately, prison records do not implicitly suffer from such a constraint and the subsequent truncation bias observed in military samples. However, prison records are not

\footnotetext{
${ }^{1}$ I am currently collecting $19^{\text {th }}$ century Irish prison records. Irish prison enumerators also used light, medium, dark, fresh and sallow to describe white prisoners in prisons from a traditionally white population. To date, no inmate in an Irish prison has been recorded with a complexion consistent with African heritage.
} 
above scrutiny. One potential bias inherent in prison records is they may be drawn from lower socioeconomic groups, although this bias may itself be an advantage to prison records, because lower socioeconomic groups are more vulnerable to economic change (Bogin, 1991, p. 288; Komlos and Baten, 2004, p. 199). The shape of the stature distribution is important in stature studies because normally distributed statures allow robust estimation with standard statistical techniques. Because the youth height distribution is itself a function of the age distribution, a youth height index is constructed that standardizes for age to determine youth stature normality. First, each youth age category's average stature is calculated. Second, each observation is then divided by the average stature for the relevant age group (Komlos, 1987, p. 899). Figure 1 demonstrates there were no arbitrary stature truncation points and statures were distributed approximately normal. 
Figure 1, National Stature Histograms by Age Group
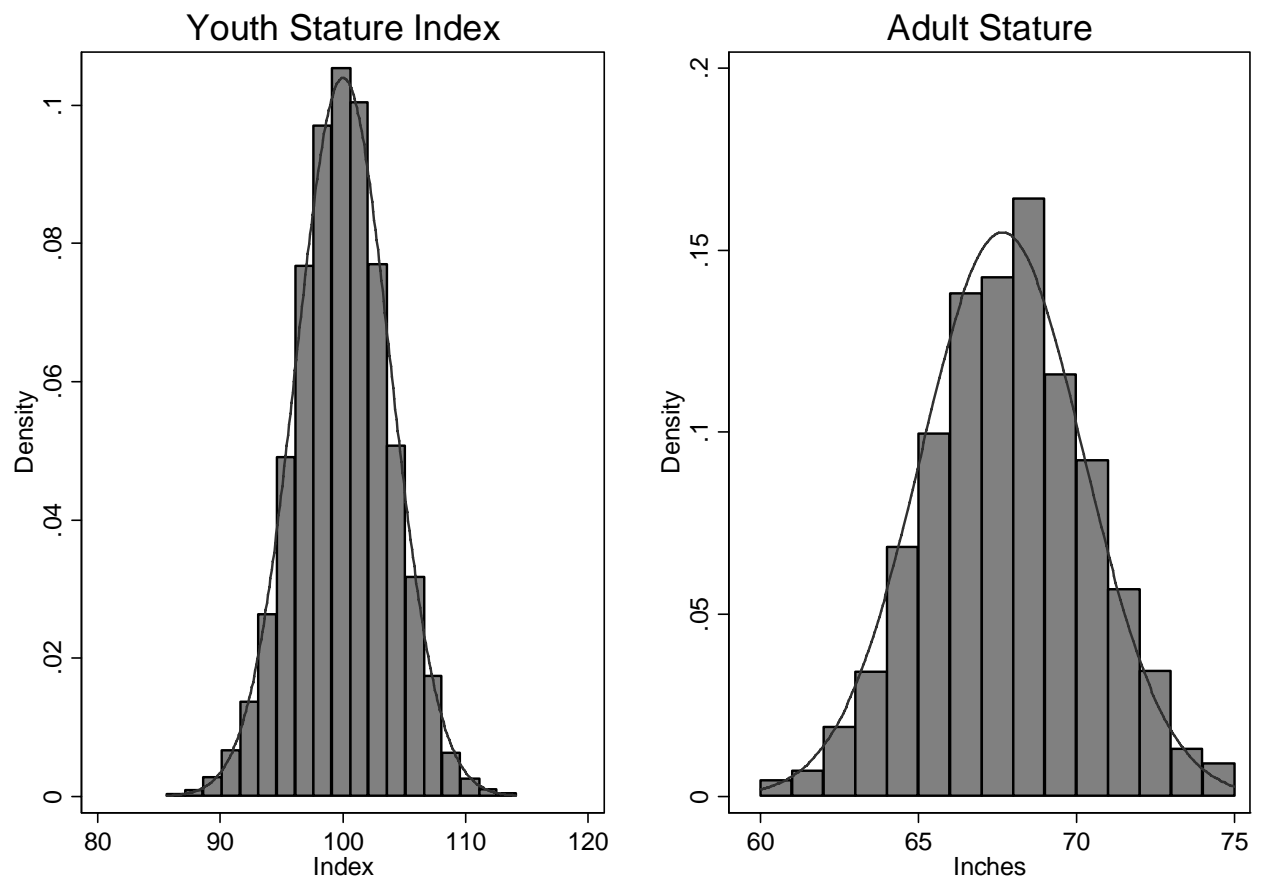

Source: see Table 1.

Occupations are a good measure for socioeconomic conditions. Enumerators recorded a broad continuum of occupations and defined them narrowly, recording over 200 different occupations, which are classified here into four categories: workers who were merchants and high skilled workers are classified as white-collar workers; light manufacturing, craft workers and carpenters are classified as skilled workers; workers in the agricultural sector are classified as farmers; laborers and miners are classified as unskilled workers (Tanner, 1977, p. 346; Ladurie, 1979; Margo and Steckel, 1992; p. 520). Unfortunately, inmate enumerators did not distinguish between farm and common 
laborers. Since common laborers probably came to maturity under less favorable biological conditions, this potentially overestimates the biological benefits of being a common laborer and underestimates the advantages of being a farm laborer. If there was little movement away from parental occupation, $19^{\text {th }}$ century occupations may also be a good indicator for the occupational environment in which individuals came to maturity (Costa, 1993, p. 367; Margo and Steckel, 1992, p. 520; Wannamethee et al, 1996, pp. 1256-1262; Nyström Peck and Lundberg, 1995, pp. 734-737). Because individuals can migrate from their birth state to other regions, only inmates incarcerated in their native state are considered here, thereby, eliminating the effects of migration on stature. By having the same prison official record characteristics over much of the period, the consistency of the prison sample creates reliable comparisons across race and time.

Table 2, Nineteen Century US Prison Inmate Demographics and Occupations

\begin{tabular}{l|cccclcccc}
\hline $\begin{array}{l}\text { Birth } \\
\text { Decade }\end{array}$ & $N$ & $\%$ & $\bar{X}$ & S.D. & Occupation & $N$ & $\%$ & $\bar{X}$ & S.D. \\
\hline 1860 & 5,175 & 47.28 & 171.43 & 6.99 & White- & 822 & 7.51 & 170.64 & 6.10 \\
& & & & & Collar & & & & \\
1870 & 5,770 & 52.72 & 171.28 & 6.69 & Skilled & 1,719 & 15.71 & 170.90 & 6.37 \\
Race & & & & & Farmer & 1,289 & 11.78 & 173.16 & 6.56 \\
Black & 3,972 & 36.29 & 171.08 & 7.20 & Unskilled & 6,746 & 61.64 & 171.36 & 7.00 \\
White & 6,973 & 63.71 & 171.51 & 6.61 & No & 369 & 3.37 & 168.54 & 6.85 \\
& & & & & Occupation & & & & \\
Received & & & & & Nativity & & & & \\
$1870 \mathrm{~s}$ & 920 & 8.41 & 169.04 & 7.21 & Northeast & 0 & 0 & Na & Na \\
$1880 \mathrm{~s}$ & 3,613 & 33.01 & 171.39 & 7.10 & Middle & 1,704 & 15.57 & 169.17 & 6.52 \\
& & & & & Atlantic & & & & \\
$1890 \mathrm{~s}$ & 4,809 & 43.94 & 171.73 & 6.50 & Great & 2,750 & 25.13 & 171.71 & 6.36 \\
& & & & & Lakes & & & & \\
$1900 \mathrm{~s}$ & 1,528 & 13.96 & 171.50 & 6.76 & Plains & 1,513 & 13.82 & 170.59 & 6.67 \\
$1910 \mathrm{~s}$ & 75 & .69 & 170.28 & 5.64 & Southeast & 738 & 6.74 & 170.55 & 6.77 \\
& & & & & Southwest & 3,510 & 32.07 & 172.82 & 7.13 \\
\hline
\end{tabular}

Source: See Table 1. 
Table 2 presents inmate proportions and heights by decade received, race, birth decade, occupations and nativity. More inmates were incarcerated during the 1870s than the 1860s, and whites were more prominent than blacks, although blacks were over represented in prisons relative to the overall population. Occupations reflect socioeconomic status, and while prison inmates typically come from lower working classes, there was a sizable proportion of inmates with white-collar and skilled occupations. Many inmates were unskilled, but not abnormally so relative to the overall population. Most inmates in the prison sample were from the Southwest, with significant proportions from Great Lakes, Plains and Middle Atlantic regions.

Table 3, National US Census Race, Residence and Occupations by Decade

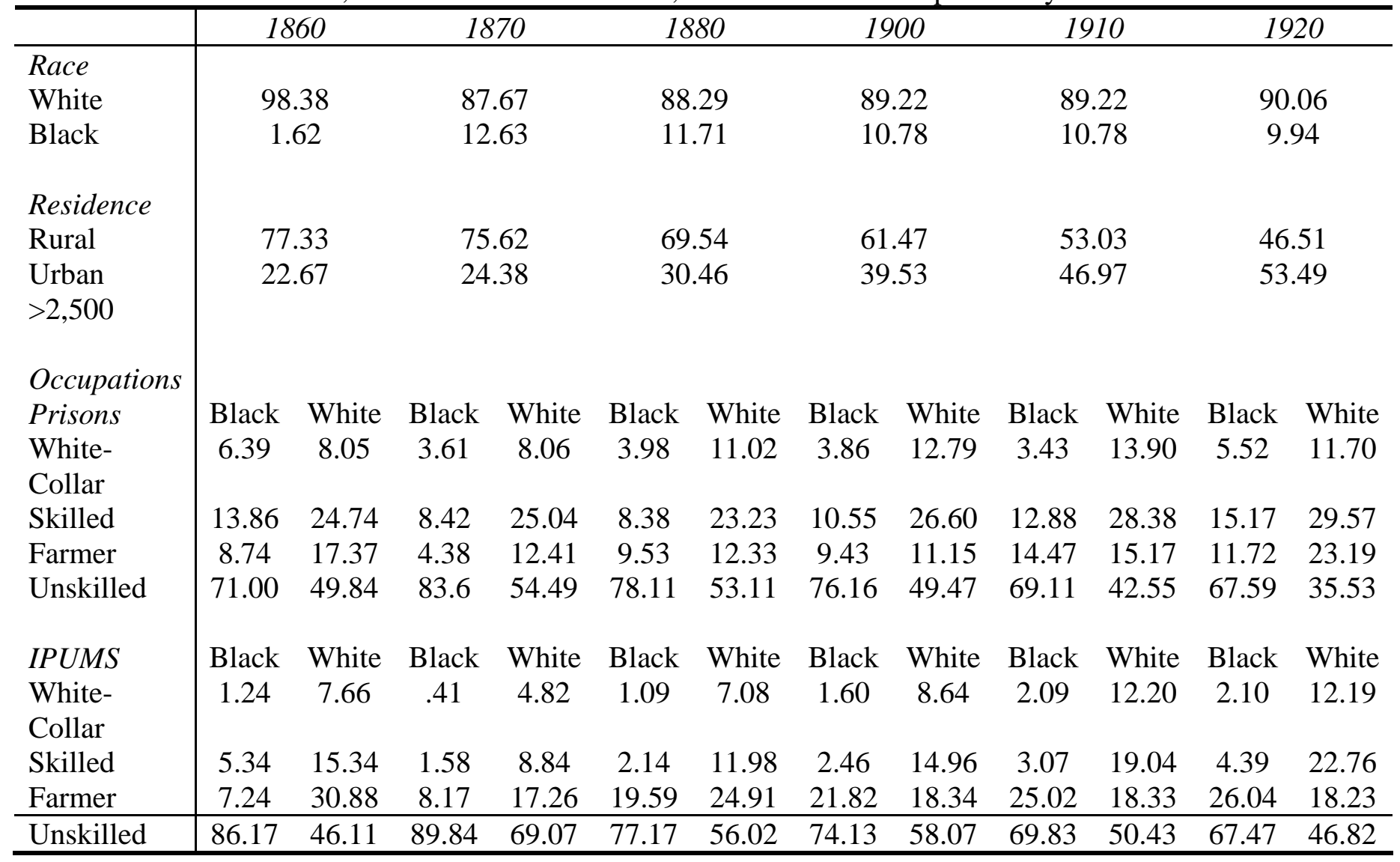

Source: Prison data, see Table 1. National population data, see Ruggles, Steven 
Matthew Sobek, Trent Alexander, Catherine A. Fitch, Ronald Goeken, Patricia Kelly Hall, Miriam King, and Chad Ronnander. Integrated Public Use Microdata Series: Version 3.0 [Machine-readable database]. Minneapolis, MN: Minnesota Population Center [producer and distributor], 2004.

How well US state prison populations reflect the US general population is observed by comparing prison to census population occupational and residential distributions. Table 3 illustrates that blacks in the US censuses were predictably less likely than whites to be white-collar, skilled workers and farmers, and were more likely to be unskilled workers. Comparing the prison to census occupations detects the counter-intuitive result that, after controlling for race, inmates were consistently more skilled than the US population. Much of this is attributable to prisoner ages that were older than the US population, further along in the occupational life-cycle, therefore, more skilled than the US labor force. Inmates' average ages were in their mid-30s; workers in the US general population sample’s average ages were in their mid-20s; however, comparing two historical data sets from different sources may be problematic because prison and census enumerators followed different recording guidelines. Given this possibility, comparing prison to census occupational distributions demonstrates that prison socioeconomic status was probably comparable with the general populations' working class (Riggs, 1964, p. 64). Likewise, the US urbanized between 1860 and 1900, and urbanization occurred along racial lines. In 1860, 22.50 percent of US whites lived in urban locations; 32.92 percent of blacks lived in urban locations. By 1900, 46.11 
percent of US whites lived in urban locations; 76.44 percent of blacks lived in urban locations (IPUMS, 1860, 1870, 1880 and 1900; Cuff, 2005, pp. 69-72).

US Average Wealth and Wealth Inequality

The 1860 and 1870 federal censuses have been the subject of numerous $19^{\text {th }}$ century wealth studies and provide unique insight into the historical relationship between material conditions, inequality and health as development occurred. Lee Soltow (1975) uses an 1860 and 1870 US wealth sample to demonstrate that wealth inequality did not start with industrialization and changed little between 1800 and 1940. Atack and Bateman (1981) use 1860 and 1870 census wealth to show that although wealth in the rural North was distributed more equitably than in the South, it was not a classical egalitarian society. Kearl, Pope and Wimmer (1981) and Pope (1989) use census records to demonstrate that wealth in the Far West was distributed more equitably; however, western wealth accumulation lagged behind that of the East.

Using the Integrated Public Use Microdata Series, US wealth inequality is considered here for male headed households over the age of 18 (Figures 2 and 3). ${ }^{2}$ Eighteen sixty and 1870 total US wealth inequality were .71606 and .71220 , respectively. On the other hand, between 1860 and 1870, average total wealth decreased from \$3,289 in 1860 to \$3,018 in 1870 (Figures 4 and 5). Northern wealth holdings increased between 1860 and 1870 while maintaining relatively high wealth equality. Nevertheless, it was the North's industrialization that may have threatened Northern biological conditions. In 1860, the South had the highest average wealth and had greater wealth inequality than the North; however, with the end of slavery average, Southern wealth declined considerably, while continuing to have high wealth inequality (Saltow, 1975;

\footnotetext{
${ }^{2}$ No upper bound is placed on ages and all US geographic regions are considered.
} 
Easterlin, 1971). Of course, the difference was Southern chattel slavery, and once slaves were freed, southern personal wealth declined.

Figure 2, 1860 US Inequality by State

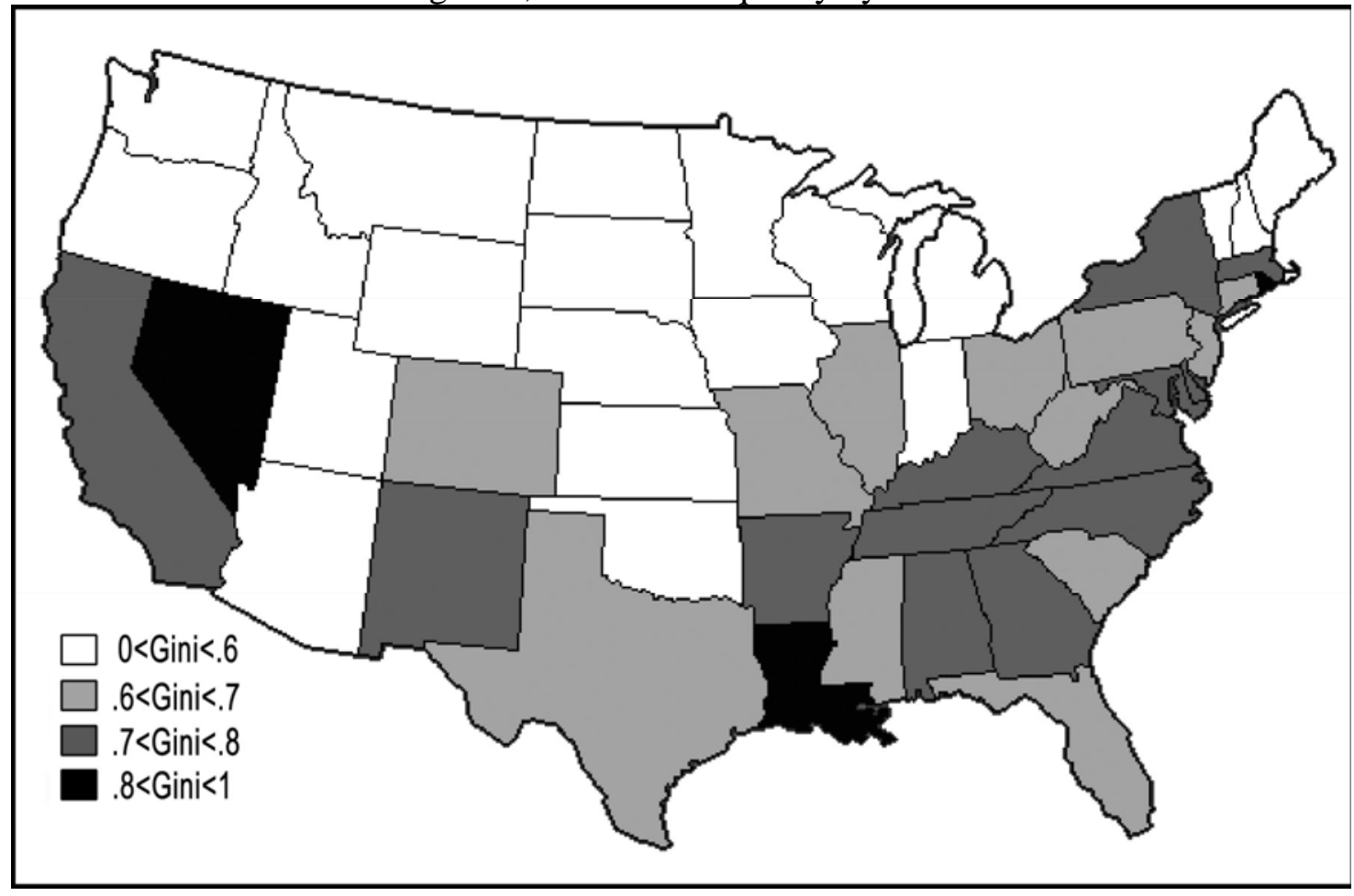


Figure 3, 1870 US Inequality by State

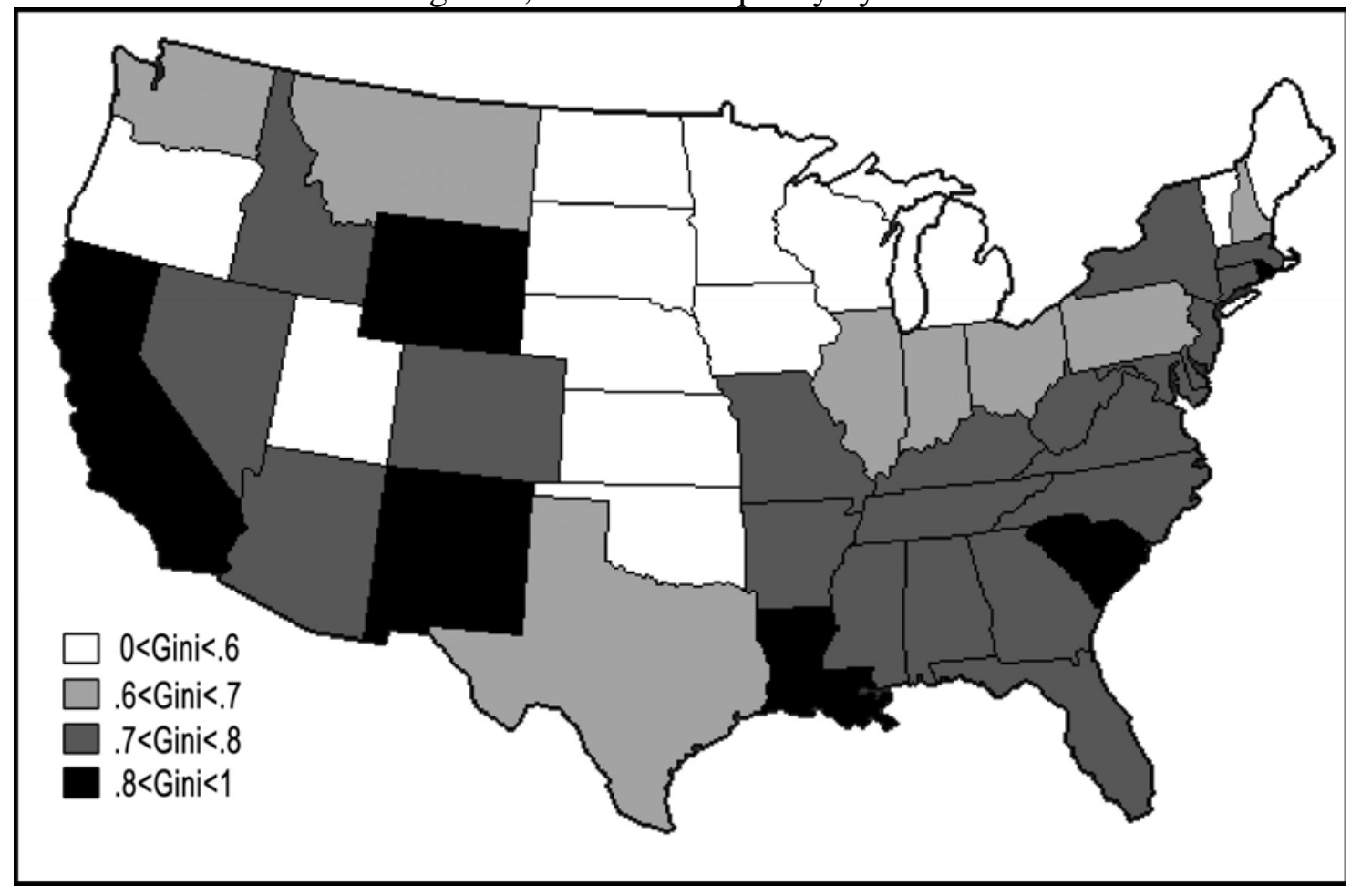

1870 Wealth Inequality 
Figure 4, 1860 US Average State Wealth

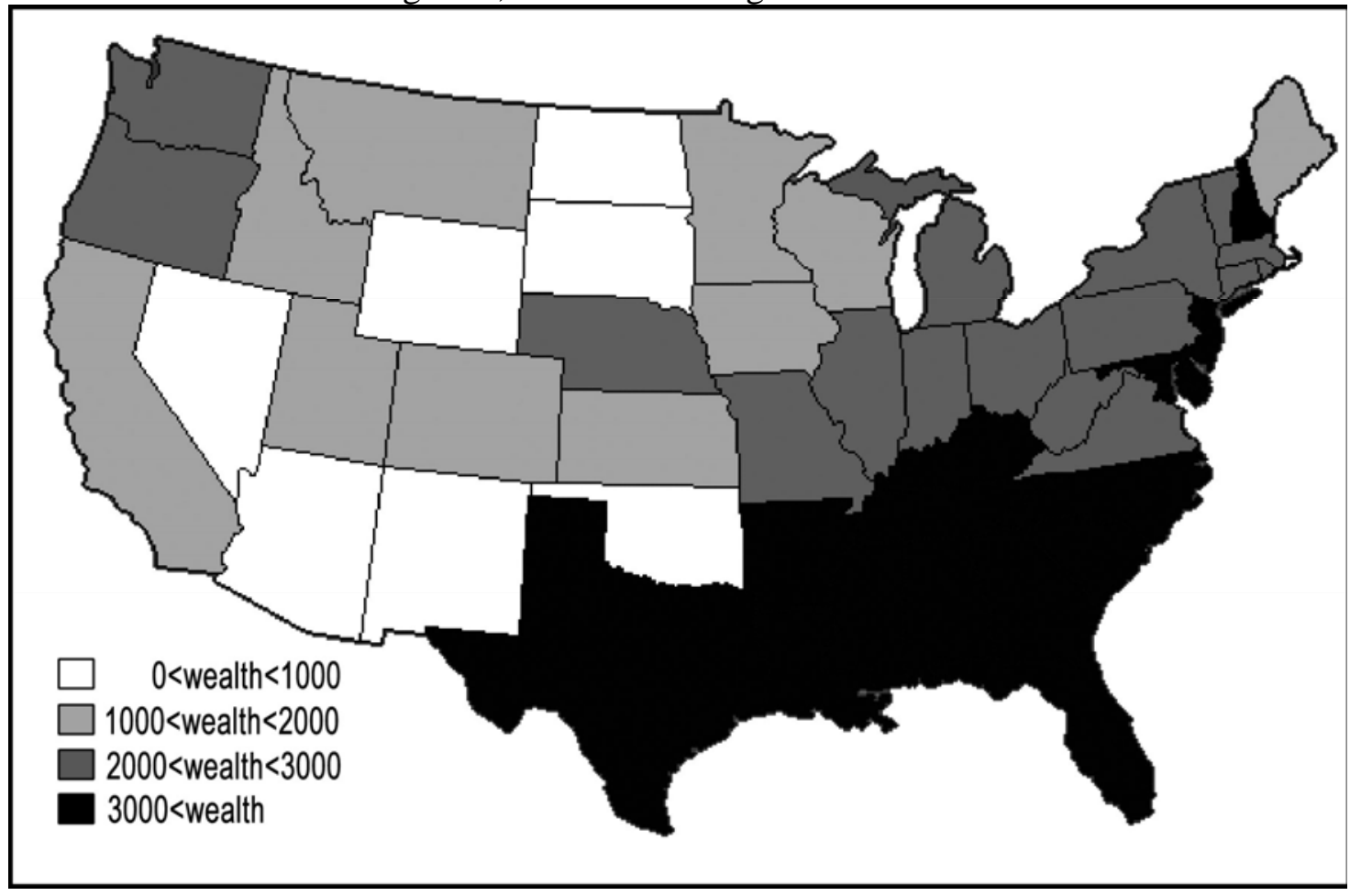

Figure 5, 1870 US Average State Wealth

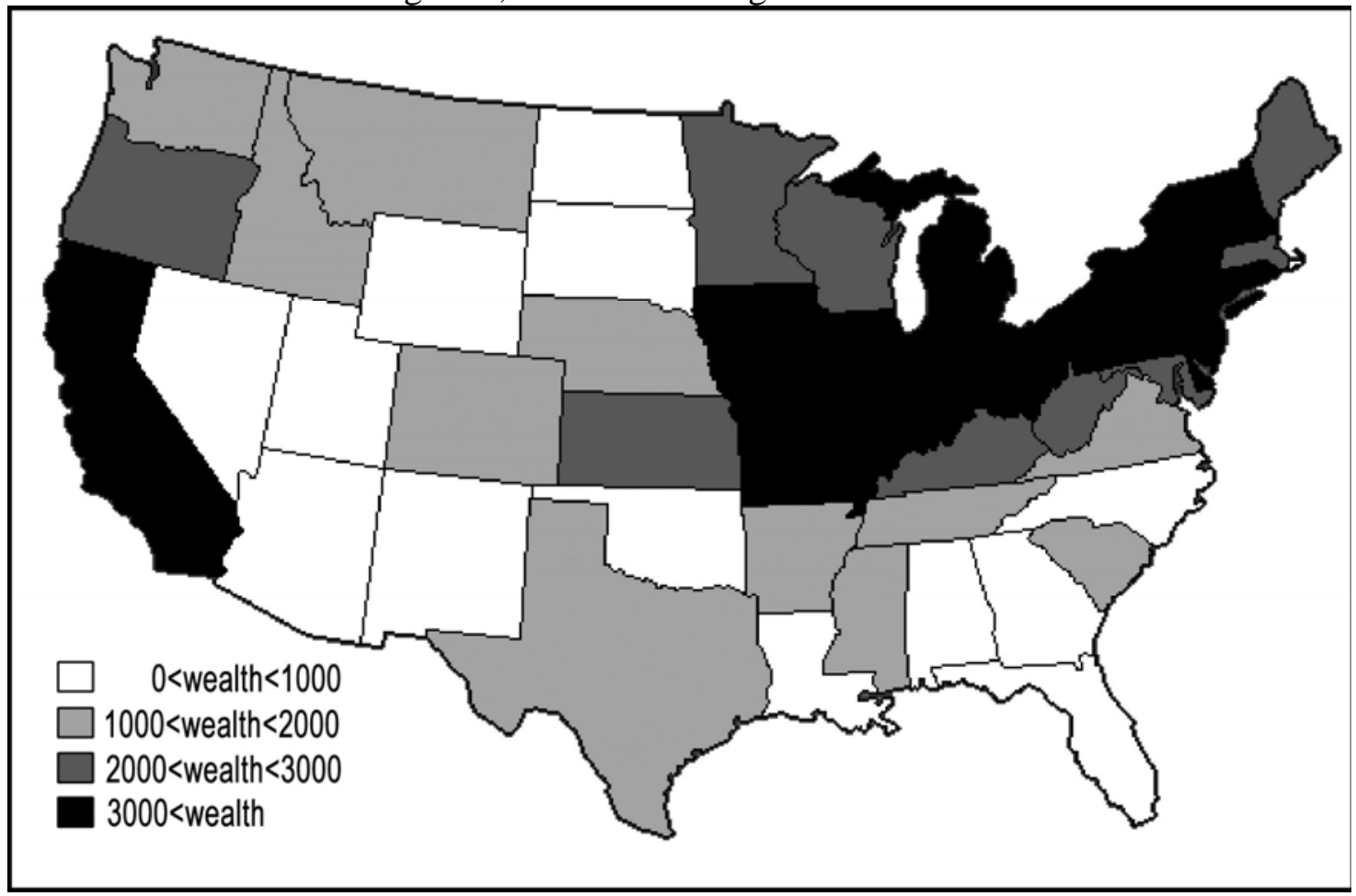




\section{Solar Radiation}

To account for the biological relationship between vitamin $\mathrm{D}$ and stature, a statelevel insolation index is constructed. Insolation is the incoming solar radiation that reaches the earth, its atmosphere and surface objects. Terminal adult statures have also been linked to vitamin D consumption (Xiong et al, 2005, pp. 228, 230-231; XZLiu et al., 2003; Ginsburg et al., 1998; Uitterlinden, 2004), and vitaming D has been linked to childhood exposure to insolation (Islam, 2007), indicating that, all else equal, taller statures should be found in geographic locations that received more insolation. Because US historical insolation is unavailable, a modern insolation index (1993-2003) is constructed by weighting each state's county insolation centroid relative to the county's proportional square miles in the state. While this index is a rough approximation for historical insolation, it provides sufficient detail to capture state and latitudinal insolation variation and reflects vitamin D production. The US receives, on average, 4.10 hours of direct sunlight per day, and varies by proximity to the equator. Predictably, Southern states have greater insolation than Northern states, and Western states have greater insolation than Eastern states. For example, Wyoming and Ohio are on similar latitudes, but Wyoming receives 4.22 hours of direct sunlight per day, while Ohio receives only 3.66 hours per day. Consequently, new $19^{\text {th }}$ century American data sources introduced here make it possible to assess the various aspects of health, wealth and inequality.

III. Individual-level Stature, Wealth, Inequality and Socioeconomic Status The timing and extent of stature variation not only reflects the cumulative relationship between diet and disease, but also the distribution of wealth, population 
density, urbanization and industrialization (Steckel, 1995, p. 1914). Table 4 presents stature relationships with age, race, insolation, wealth, inequality, socioeconomic status, and population density. Model 1 presents the unrestricted stature model and includes race, insolation, demographic, wealth, inequality and population density variables as defined above; subsequent restricted models are presented to illustrate characteristic associations with stature and to demonstrate the consequences of omitted variables. Model 2 omits insolation variables; model 3 omits wealth variables; model 4 omits socioeconomic variables; model 5 does the same for population density variables. To account for non-linear relationships with stature, polynomial terms are included for insolation, wealth, and population density. 
Table 4, 1860 and 1870 US Prison Statures, Demographics, Insolation, Wealth and Population Density

\begin{tabular}{|c|c|c|c|c|c|c|c|c|c|c|}
\hline & Model 1 & & Model 2 & & Model 3 & & Model 4 & & Model 5 & \\
\hline & Unrestricted & $\begin{array}{c}\mathrm{p}- \\
\text { value }\end{array}$ & $\begin{array}{c}\text { Insolation } \\
\text { Restriction }\end{array}$ & $\begin{array}{c}\mathrm{p}^{-} \\
\text {value }\end{array}$ & $\begin{array}{c}\text { Wealth } \\
\text { Restriction }\end{array}$ & $\begin{array}{c}\mathrm{p}^{-} \\
\text {value }\end{array}$ & $\begin{array}{c}\text { Socioeconomic } \\
\text { Status } \\
\text { Restriction }\end{array}$ & $\begin{array}{c}\mathrm{p}- \\
\text { value }\end{array}$ & $\begin{array}{l}\text { Population } \\
\text { Density } \\
\text { Restriction }\end{array}$ & $\begin{array}{c}\mathrm{p}^{-} \\
\text {value }\end{array}$ \\
\hline $\begin{array}{l}\text { Constant } \\
\text { Race }\end{array}$ & 110.27 & $<.01$ & 190.61 & $<.01$ & -33.04 & .09 & 102.32 & $<.01$ & 124.18 & $<.01$ \\
\hline White & Reference & & Reference & & Reference & & Reference & & Reference & \\
\hline $\begin{array}{l}\text { Black } \\
\text { Ages }\end{array}$ & -1.85 & $<.01$ & -1.79 & $<.01$ & -1.38 & $<.01$ & -1.80 & $<.01$ & -1.84 & $<.01$ \\
\hline 14 & -11.28 & $<.01$ & -11.29 & $<.01$ & -11.77 & $<.01$ & -11.32 & $<.01$ & -11.36 & $<.01$ \\
\hline 15 & -9.69 & $<.01$ & -9.66 & $<.01$ & -10.09 & $<.01$ & -9.81 & $<.01$ & -9.84 & $<.01$ \\
\hline 16 & -4.69 & $<.01$ & -4.69 & $<.01$ & -4.98 & $<.01$ & -4.70 & $<.01$ & -4.84 & $<.01$ \\
\hline 17 & -3.15 & $<.01$ & -3.18 & $<.01$ & -3.19 & $<.01$ & -3.16 & $<.01$ & -3.19 & $<.01$ \\
\hline 18 & -2.02 & $<.01$ & -2.05 & $<.01$ & -1.99 & $<.01$ & -2.02 & $<.01$ & -2.05 & $<.01$ \\
\hline 19 & -.252 & .34 & -.264 & .31 & -.291 & $<.01$ & -.256 & .33 & -.300 & .26 \\
\hline $20 \mathrm{~s}$ & Reference & & Reference & & Reference & & & & Reference & \\
\hline $30 \mathrm{~s}$ & .005 & .98 & .038 & .81 & -.099 & .54 & -.067 & .68 & -.027 & .87 \\
\hline $40 \mathrm{~s}$ & -.337 & .28 & -.328 & .29 & -.325 & .30 & -.445 & .16 & -.346 & .27 \\
\hline $\begin{array}{l}50 \mathrm{~s} \\
\text { Insolation }\end{array}$ & -3.49 & $<.01$ & -3.38 & .01 & -3.68 & $<.01$ & -3.58 & $<.01$ & -3.52 & $<.01$ \\
\hline Insolation & 34.02 & $<.01$ & & & 87.67 & $<.01$ & 38.11 & $<.01$ & 30.24 & $<.01$ \\
\hline $\begin{array}{l}\text { Insolation }{ }^{2} \\
\text { Wealth } \\
\text { Variables }\end{array}$ & -3.64 & $<.01$ & & & -9.30 & $<.01$ & -4.10 & $<.01$ & -3.55 & $<.01$ \\
\hline Total Wealth & -.005 & $<.01$ & -.005 & $<.01$ & & & -.006 & $<.01$ & -.005 & $<.01$ \\
\hline Total Wealth ${ }^{2}$ & $8.3^{-7}$ & $<.01$ & $8.3^{-7}$ & $<.01$ & & & $8.8^{2}$ & $<.01$ & $7.4^{-7}$ & $<.01$ \\
\hline $\begin{array}{l}\text { Gini coefficient } \\
\text { Time }\end{array}$ & -.175 & $<.01$ & -.202 & $<.01$ & & & -.176 & $<.01$ & -.142 & $<.01$ \\
\hline 1860 & Reference & & Reference & & Reference & & & & Reference & \\
\hline 1870 & .456 & .05 & 1.03 & $<.01$ & -1.19 & $<.01$ & .435 & $<.01$ & .435 & $<.01$ \\
\hline
\end{tabular}




\begin{tabular}{|c|c|c|c|c|c|c|c|c|c|c|}
\hline \multicolumn{11}{|l|}{ State } \\
\hline $\begin{array}{l}\text { Population } \\
\text { Population } \\
\text { density }\end{array}$ & .167 & $<.01$ & .127 & $<.01$ & .093 & $<.01$ & .176 & $<.01$ & & \\
\hline $\begin{array}{l}\text { Population } \\
\text { density }^{2} \\
\text { Socioeconomic } \\
\text { Status }\end{array}$ & -.002 & $<.01$ & -.002 & $<.01$ & $6.4^{-4}$ & $<.01$ & -.002 & $<.01$ & & \\
\hline $\begin{array}{l}\text { White-Collar } \\
\text { and Skilled }\end{array}$ & Reference & & Reference & & Reference & & Reference & & Reference & \\
\hline Farmer & 1.82 & $<.01$ & 1.86 & $<.01$ & 2.04 & $<.01$ & & $<.01$ & 1.87 & $<.01$ \\
\hline Unskilled & .766 & $<.01$ & .760 & $<.01$ & .867 & $<.01$ & & $<.01$ & .750 & $<.01$ \\
\hline $\mathrm{N}$ & 10,935 & & 10,935 & & 10,935 & & 10,935 & & 10,935 & \\
\hline $\mathrm{R}^{2}$ & .1116 & & .1107 & & .0915 & & .1060 & & .1081 & \\
\hline
\end{tabular}

Source: See Table 1.

Notes: Because US historical insolation is unavailable, a modern insolation index (1993-2003) is constructed, and monthly insolation values are measured from

January thru June. The insolation index measures the hours of direct sunlight per day at county centroids in each state and is weighted by a county's square miles

relative to square miles in the state. ${ }^{3}$ While this index is a rough approximation for historical insolation, it provides sufficient detail to capture state latitudinal

insolation variation and consequently, vitamin D production.

\footnotetext{
${ }^{3}$ Insolation is not the insolation in the county that surround's the state's centroid, but insolation in each county's geographic center. The range of state insolation values extends from Maine's minimum of 3.43 hours of direct sunlight to Arizona’s maximum of 5.22 hours of direct sunlight per day.
} 
For the most part, stature relationships with race, insolation, wealth, socioeconomic status, and population density are consistent with expectations, and in each case, polynomial terms are significant, indicating there were diminishing returns to stature in insolation, wealth and population density.

\section{Wealth and Inequality}

There are two ways in which wealth influences stature, and these mechanisms are broadly classified here into the absolute and relative wealth hypotheses. First, stature increases with absolute or average wealth because material wealth directly creates greater access to nutritious diets, and during the $19^{\text {th }}$ century, wealth was tied to access to land, which probably contributed to taller statures (Steckel, 1995, p. 1914; Komlos, 1987, pp. 903; Komlos, 1998). Moreover, the relationship between stature and wealth may be nonlinear, because after basic dietary needs are met, individuals allocate proportionally fewer resources to nutrition, and additional calories do not contribute to stature growth. The second hypothesis — the relative wealth hypothesis—is that stature decreases with wealth inequality because inequality decreases access to health inputs—such as nutrition and medical intervention — and forecloses those in lower socioeconomic groups from nutrition and other health inputs (Williamson and Pickett, 2006, p. 1775). Alternatively, relative equality allows individuals in lower socioeconomic groups to reach their stature potentials, thereby, increasing average stature.

Table 4 demonstrates that greater average state wealth was associated with taller statures, and stature increased with average wealth at a decreasing rate. Furthermore, wealth inequality was ubiquitously associated with shorter statures (Steckel, 1995). For 
example, a 10 percent difference in inequality across states was associated with 1.75 centimeter shorter statures. Therefore, $19^{\text {th }}$ century wealth inequality had real health consequences, and there may be more of a relationship between health and inequality when the relationship is measured between cumulative wealth inequality and stature. Moreover, a joint hypothesis test on wealth and inequality demonstrates that wealth and inequality were significantly related with stature ([F-Statistic, 126.47; $\mathrm{p}=.0000]$ ), and wealth variable omissions upwardly bias stature relationship with insolation, indicating that when wealth is omitted the asymptotic bias to stature with insolation is positive (Woodridge, 2002, p. 62; Woolridge, 2003, p. 92, Table 3.2).

\section{Race and Insolation}

Any discussion of $19^{\text {th }}$ century stature must account for the racial and cultural relationship between whites and blacks. When brought to maturity under optimal net nutritional conditions, blacks and whites reach comparable adult terminal statures (Eveleth and Tanner, 1966, Appendix. Tables 5, 29, and 44; Tanner, 1977, pp. 341-342; Margo and Steckel, 1982; Komlos and Lauderdale, 2005); however, $19^{\text {th }}$ century blacks were consistently shorter than whites. Margo and Steckel (1982), Sünder (2004) and Carson (2007) demonstrate that antebellum Southern whites were nearly 2 inches taller than Southern blacks, and adult male slaves were shorter than northern whites (Margo and Steckel, 1982, p. 519). Moreover, compositional effects can not explain the stature differential, which was due, in part, to white's access to meat and better nutrition (Margo, and Steckel, 1982, p. 514-515, 517 and 519). Two potential explanations are offered to explain this $19^{\text {th }}$ century black-white stature differential. First, blacks may have been shorter than whites because socioeconomic and racial preferences disproportionately 
favored whites to blacks (Steckel, 1979; Bodenhorn, 1999; Komlos, 1998; Rees et al., 2003). However, this sociological explanation may not fully account for a persistent pattern: Northern whites were taller than Northern blacks and Southern whites were taller than Southern blacks.

A second spatial-biological explanation is that blacks may have been shorter than whites because more exposure to direct sunlight produces more vitamin $\mathrm{D}$, and greater vitamin D consumption has been linked to taller adult terminal statures (Xiong, 2005, pp. 228-231; XZLui et al, 2003; Ginsburg et al., 1998; Uitterlinden et al., 2004). Calcium and vitamin D are needed throughout life for optimal stature growth, and both were sensitive to $19^{\text {th }}$ century physical locations. Access to agricultural products determine accessibility to calcium, and individuals living in areas that specialized in dairy production had greater access to —-therefore lower costs of acquiring—calcium. Vitamin D’s primary source is not dietary but comes from sunlight's synthesis with cholesterol into vitamin D in the epidermis’s stratus granuloseum (Loomis, 1967, pp. 501-504; Holick, 1995, 2004 and 2007). However, black and white epidermises are not equally efficient in vitamin D synthesis. Greater melanin in the stratus corneum reduces darker skin’s vitamin D production and lighter skin is between 50 and 90 percent more efficient at synthesizing sunlight and cholesterol into vitamin D (Holick, 2004, p. 364). Calcium and vitamin D as potential sources for the black-white stature differential are even more plausible because until the 1930s, the US food supply was not fortified with vitamin D. ${ }^{4}$ Individuals born in states that received more insolation were taller than individuals who lived in areas that received less insolation, which is supported by modern population studies (Norman, 1998, pp. 1108-1110; Weisberg et al, p. 1703S-1704S;

\footnotetext{
${ }^{4}$ See Table 4 notes for how the insolation index is constructed.
} 
Holick, 1995, pp. 641S-642S; Nesby-O’Dell et al 2002, p. 189). Individuals were taller in Southern states, such as Texas, which receives approximately 4.5 hours of direct sunlight per day. However, stature was associated with factors other than direct hours of sunlight per day. For example, Arizona and New Mexico are two states that receive more insolation than Texas, but were materially poorer, with wealth distributed less equitably than Texas. In 1870, Texas’ average wealth was \$1,247; average Arizona and New Mexico wealth were $\$ 588$ and $\$ 438$, respectively. In 1870 , the Texas gini coefficient was .67536; Arizona and New Mexico gini coefficients were .74928 and .80209, respectively, demonstrating there were plausible stature trade-offs between the environment, material wealth and inequality. Moreover, a joint hypothesis test demonstrates insolation and race were significantly related with stature ([FS 47.21], $\mathrm{p}=.0000$ ), and insolation's omission does not change slope coefficients for other variables but only changes the model's intercept.

Socioeconomic Status and Population Density

Nineteenth century health and stature outcomes were related to occupations and socioeconomic status, and like other studies, farmers reached taller terminal statures than workers in other occupations (Costa, 1993, p. 367;Komlos and Coclanis, 1997; Komlos, 1987; Steckel, and Haurin, 1994; Margo and Steckel, 1982; Sokoloff and Villaflor, 1982). Unskilled workers were also surprisingly tall, which suggests prison enumerators combined farm laborers with common laborers, and part of the explanation for taller farmers and unskilled workers may have also been related to vitamin D. Islam et al. (2007, pp. 383-388) demonstrates that children exposed to more direct sunlight produce more vitamin D, and if there was little movement away from parental occupation, $19^{\text {th }}$ 
century occupations may also be a good indicator for the occupational environment in which individuals came to maturity (Costa, 1993, p. 367; Margo and Steckel, 1992, p. 520; Wannamethee et al, 1996, pp. 1256-1262; Nyström Peck and Lundberg, 1995, pp. 734-737). Farming is an outdoor occupation, which exposes farmers to more direct sunlight, and $19^{\text {th }}$ century farmers were taller than workers in other occupations by about two centimeters (Komlos and Coclanis, 1997, p. 441; Komlos, 1987, p. 902; Steckel and Haurin, 1994, p. 170; Sokoloff and Villaflor, 1982, p. 463; Margo and Steckel, 1983, pp. 171-172), suggesting part of the $19^{\text {th }}$ century farmer stature advantage was also related to insolation. A joint hypothesis test on socioeconomic status demonstrates socioeconomic status was significantly related with stature ([FS, 36.61], $\mathrm{p}=.0000)$, and socioeconomic status omissions do not significantly change slope coefficients for other variables.

Health and stature outcomes are also related to population density (Steckel, 2005), and stature was positively related with population density in states with less than 42 persons per square miles; maximum stature was attained in states that had population densities of 42 persons per square mile, which is comparable to Illinois' population density. However, individuals in states with greater than 42 persons per square mile had an inverse relationship between stature population density (Komlos and Lauderdale, 2005, pp. 59, 65, and 72). Moreover, part of the stature relationship with population density may itself be a result of measurement. If population density is measured at the local-level, local-level measurements may illustrate the effects of close proximity to water transport systems and disease environments. If, however, population density is measured at the state-level, the relationship between stature and population density may capture the relationship between state-level economic development and stature. 
Moreover, a joint hypothesis test on population density demonstrates population density was jointly associated with stature ([FS, 22.12], $\mathrm{p}=.0000$ ), and population density omissions do not significantly change slope coefficients of other variables but only change model intercepts.

\section{Discussion}

Evidence presented here addresses missing pieces in the health and stature puzzles, and $19^{\text {th }}$ century health was related to material inequality, supporting the general conclusion that inequality has deleterious health effects (Williamson, 2006, p. 1775; Steckel, 1995). Moreover, the relationship between inequality and health indicates that part of the diverse opinions regarding the relationship between health and inequality depends on how the relationship is measured. For example, Deaton (2002, p. 115) demonstrates there is little relationship between current income inequality and mortality rates, both measures for current health. However, when health is measured in stature and wealth — two cumulative measures for health and material living conditions - there is an inverse relationship between wealth inequality and health (Steckel, 1995).

Other relationships are consistent with expectations. Although blacks and whites come to similar statures when brought to maturity under optimal biological conditions, $19^{\text {th }}$ century American whites were consistently taller than American blacks, and part of the black stature deficit may be the result of their living in physical environments where they were not biologically suited. Stature was related to socioeconomic status, where farmers and laborers were closer to healthy biological conditions, and grew taller than white-collar and skilled workers. Finally, statures were shorter in lesser populated states and increased with population density; however, population densities in excess of those 
comparable to the mid-west were associated with shorter statures and possibly poorer health. 
Work Cited

Atack, Jeremy and Fred Bateman, 1980, “The Egalitarian Ideal” and the Distribution of

Wealth in the Northern Agricultural Community: A Backward Look.” Review of Economics and Statistics, 63(1), pp.124-129.

Atack, Jeremy and Fred Bateman, To Their Own Soil: Agriculture in the Antebellum North. Ames, Iowa: Iowa State University Press, 1987.

Bodenhorn, Howard. “A Troublesome Caste: Height and Nutrition of Antebellum Virginia’s Rural Free Blacks.” Journal of Economic History. 59, no. 4 (December, 1999): 972-996.

Bogin, Barry, 1991, “Measurement of Growth Variability and Environmental Quality in Guatemalan Children,” Annals of Human Biology 18, pp. 285-294.

Carson, Scott Alan. “African -American and White Inequality in the $19^{\text {th }}$ Century American South: A Biological Comparison,” Journal of Population Economics. Forthcoming.

Costa, Dora, 1993, "Height, Wealth and Disease among the Native-Born in the Rural Antebellum North,” Social Science History Association, 17(3), pp. 355-383. Cuff, Timothy, 2005, The Hidden Cost of Economic Development: The Biological Standard of Living in Antebellum Pennsylvania. Vermont: Ashgate.

Cutler, David, (2004), Your Money or Your Life: Strong Medicine for America's Healthcare System, Oxford University Press: New York.

Deaton, Angus (2002) “Health, Inequality and Economic Development,” Journal of Economic Literature, 41(1), pp. 113-158.

Easterlin, Richard. “Regional Income Trends, 1840-1950.” in The Reinterpretation of 
American Economic History, edited Robert Fogel and Stanley

Engerman. New York: Harper \& Row. 1971. 38-53.

Eveleth, Phillis B. and James M. Tanner. Worldwide Variation in Human Growth.

Cambridge: Cambridge University Press. 1966. Second Ed. 1990.

Fogel, Robert, Stanley Engerman, James Trussell, Roderick Floud, Clayne Pope, and

Larry Wimmer, “Economics of Mortality in North America, 1650-1910: A

Description of a Research Project,” Historical Methods, 11(2), 1978, pp. 75-108.

Ginsburg, E, G. Livshits, K. Yakovenko and E. Kobyliansky, "Major Gene Control of Human Body Height, Weight and BMI in Five Ethnically Different Populations,” Annals of Human Genetics, 62, 1998, pp. 307-322.

Granvelle, Hugh, “How Much of the Relationship between Population Mortality and Unequal Distribution of Income is a Statistical Artifact?” British Medical Journal 316, 1998, pp. 382-385.

Holick, Michael F, “Environmental Factors that Influence the Cutaneous Production of Vitamin D.” American Journal of Clinical Nutrition 61, 1995, pp. 638S-645S.

Holick, Michael F, “Vitamin D: Importance in the Prevention of Cancers, Type 1

Diabetes, Heart Disease and Osteroporosis.” American Journal of Clinical Nutrition 79. 2004. pp. 362-371.

Holick, Michael F, 2007 “Vitamin D Deficiency.” New England Journal of Medicine 357(3). pp. 266-281.

Islam, Talat, W. James Gauderman, Wendy Cozen, Thomas Mack, 2007, “Childhood Sun Exposure Influences Rick of Multiple Sclerosis in Monozygotic Twins,” Neurology 69, pp. 381-388. 
Kearl, James R., Clayne L. Pope and Larry T. Wimmer. "Household Wealth in a Settlement Economy: Utah, 1850-187." Journal of Economic History. 40(3), 1981, 477-96.

Komlos, John. "The Height and Weight of West Point Cadets: Dietary Change in Antebellum America.” Journal of Economic History 47, no. 4 (December 1987): 897-927.

Komlos, John. “Toward an Anthropometric History of African-Americans: The Case of the Free Blacks in Antebellum Maryland.” in Strategic Factors in Nineteenth Century American Economic History: A Volume to Honor Robert W. Fogel, edited by Claudia Goldin and Hugh Rockoff. Chicago: University of Chicago Press. 1992, 297-329.

Komlos, John. "Shrinking in a Growing Economy? The Mystery of Physical Stature during the Industrial Revolution.” Journal of Economic History 58, no. 3 (September, 1998): 779-802.

Komlos, John and Peter Coclanis. “On the Puzzling Cycle in the Biological Standard of Living: The Case of Antebellum Georgia.” Explorations in Economic History. 34, no. 4 (October, 1997): 433-59.

Komlos, John and Jörg Baten (2004) “Anthropometric Research and the Development of Social Science History. Social Science History. 28(2), pp. 191-210.

Komlos, John and Benjamin Lauderdale, 2005, “Spatial Correlates of US Heights and Body Mass Inexes, 2002,” Journal of Biosocial Science 39, pp. 59-78.

Le Roy Ladurie, E., 1979, The Conscripts of 1968: A Study of the Correlation between Geographical Mobility, Delinquency and Physical Stature and Other Aspects of 
the Situation of the Young Frenchman Called to Do Military Service that Year. In: Reynolds B, Reynolds S, editors. The Territory of the Historian, (Chicago: University of Chicago Press). 33-60.

Loomis, W. Farnsworth, 1967, “Skin-Pigment Regulation of Vitamin-D Biosynthesis in Man: Variation in Solar Ultraviolet at Different Latitudes may have Caused Racial Differentiation in May,” Science, pp. 501-506.

Lynch, John W., George Kaplan, Elsie R. Pamuk, Richard D. Cohen, Catherine E. Heck, Jennifer L. Balfour and Irene Yen. "Income Inequality and Mortality in Metropolitan Areas of the United States,” American Journal of Public Health, 88, 1990. pp. 1074-1080.

Margo, Robert and Richard Steckel. "Heights of American Slaves: New Evidence on Nutrition and Health.” Social Science History 6, no. 4 (Fall, 1982): 516-538. Margo, R., \& Steckel, R.H. (1983) "Heights of Native Born Northern Whites during the Antebellum Era.” Journal of Economic History 43, 167-174.

Margo, Robert and Richard Steckel. 1992 “The Nutrition and Health of Slaves and antebellum Southern whites.” in Without Consent or Contract: Conditions of Slave Life and the Transition to Freedom, edited by R. W. Fogel and S. L. Engerman, New York: Norton, 508-521.

Nesby-O’Dell, Shanna, Kelley Scanlon, Mary Cogswell, Cathleen Gillesie, Bruce Hollis Anne Looker, Chris Allen, Cindy Doughertly, Elaine Gunter, and Barbara Bowman. "Hypovitaminosis D Prevalence and Determinants among AfricanAmerican and White Woman of Reproductive Age: Third National Health and 
Nutrition Examination Survey, 1988-1994.” American Journal Clinical Nutrition 76. 2002. pp. 187-192.

Norman, Anthony, “Sunlight, Season, Skin Pigmentation, Vitamin D and 25hydroxyvatamin D: Integral Components of the Vitamin D Endocrine System,” American Journal of Clinical Nutrition, 67. 1998, pp. 1108-1110.

Nyström-Peck, Maria and Olle Lundberg, 1995, “Short Stature as an Effect and Social Conditions in Childhood,” Social Science Medicine 41(5), pp. 733-738.

Pope, Clayne (1989) "Households on the American Frontier: the Distribution of Income and Wealth in Utah, 1850-190." Markets in History. ed. David Galenson, Cambridge University Press. 148-189.

Rees, R., John Komlos, Ngo Long and Ulrich Woitek. “Optimal Food Allocation in a Slave Economy.” Journal of Population Economics, v. 16, 2003: 21-36.

Riggs, Paul, 1994, “The Standard of Living in Scotland, 1800-1850,” in Komlos, John (ed.), Stature, Living Standards and Economic Development: Essays in Anthropometric History. University of Chicago Press: Chicago.

Ruggles, Steven Matthew Sobek, Trent Alexander, Catherine A. Fitch, Ronald Goeken, Patricia Kelly Hall, Miriam King, and Chad Ronnander. Integrated Public Use Microdata Series: Version 3.0 [Machine-readable database]. Minneapolis, MN: Minnesota Population Center [producer and distributor], 2004.

Sokoloff, K. \& Villaflor, G. (1982) “Early Achievement of Modern Stature in America,” Social Science History 6, 453-481.

Soltow, Lee (1975) Men and Wealth in the United States, 1850-1870. Yale University Press: New Haven. 
Steckel, Richard, 1979, “Slave Height Profiles from Coastwise Manifests,” Explorations in Economic History 16, pp. 363-380.

Steckel, Richard H. “Height and Per Capita Income.” Historical Methods, 16. Winter 1983.

Steckel, R.H. (1995) “Stature and the Standard of Living.” Journal of Economic Literature 33, 1903-1940.

Steckel, R.H. \& Haurin, D. (1994) "Health and Nutrition in the American Midwest: Evidence from the Height of Ohio National Guardsman 1850-1910.” In: Komlos, J. (Ed.), Stature, Living Standards and Economic Development. University Press of Chicago, Chicago, 117-128.

Sunder, Marco (2004) “The Height of Tennessee Convicts: Another Pieces of the “Antebellum Puzzle”. Economics and Human Biology. pp. 75-86.

Tanner, James M, 1977, “Human Growth and Constitution,” in Harrison, GA, Weiner, JS, Tanner, JM, and Barnicot, NA (eds) Human Biology: an Introduction to Human Evolution, Variation, Growth and Ecology. pp. 301-384.

Utterlinden, André, Yue Fang, Joyce B.J. van Meurs, Huibert A. P. Pols, Johannes P.T.M van Leeuwen, “Genetic and Biology of Vitamin D Receptor Polymorphisms,” Gene, 338, 2004, pp. 143-156.

Wannamethee, S. Goya, Peter Whincup, Gerald Shaper and Mary Walker, “Influence of Father's Social Class on Cardiovascular Disease in Middle-Aged Men,” The Lancet, 348:9, 1996, pp.1259-63.

Weisberg, Pamela, Kelley Scanlon, Ruowei Li, and Mary E. Cogswell. “Nutritional Rickets Among Children in the United States: Review of Cases Reported between 
1986 and 2003.” American Journal of Nutrition 80 (suppl), 2004, pp.1697S1705S.

Wilkinson, Richard G. , 1996, Unhealthy Societies: the Affects of Inequality, New York: Routedge.

Wilkinson, Richard G. and Kate E. Pickett, 2006, “Income Inequality and Population Health: A Review and Explanation of the Evidence,” Social Science and Medicine 62, pp. 1768-1784.

Woolridge, Jeffrey, 2002, Economic Analysis of Cross Section and Panel Data. MIT Press: Cambridge, MA.

Woolridge, Jeffrey, 2003, Introductory Econometrics: a Modern Approach, $2^{\text {nd }}$ ed. Thomson South-Western, USA.

Xiong, E-H, F-H Xu, P-Y Liu, H Shen, J-R Long, L Elze, R R Recker and H-W Deng, “Vitamin D Receptor Gene Polymorphisms are Linked to and Associated with Adult Height,” Journal of Medical Genetics, 42, 2004, pp. 228-234.

Y-Z Liu, F-H Shen, H Deng, Y-J Liu, L-J Zhao, V Dvornyk, T Conway, J-L Li, Q-Y Huang, K M Davies, R R Recker, and H-W Deng, “Confirmation Linkage Study in Support of the X Chromosome Harbouring a ATL Underlying Human Height Variation,” Journal of Medical Genetics, 40, pp. 825-831. 


\section{CESifo Working Paper Series}

for full list see www.cesifo-group.org/wp

(address: Poschingerstr. 5, 81679 Munich, Germany, office@cesifo.de)

2192 Jan Bouckaert, Hans Degryse and Theon van Dijk, Price Discrimination Bans on Dominant Firms, January 2008

2193 M. Hashem Pesaran, L. Vanessa Smith and Takashi Yamagata, Panel Unit Root Tests in the Presence of a Multifactor Error Structure, January 2008

2194 Tomer Blumkin, Bradley J. Ruffle and Yosef Ganun, Are Income and Consumption Taxes ever really Equivalent? Evidence from a Real-Effort Experiment with Real Goods, January 2008

2195 Mika Widgrén, The Impact of Council's Internal Decision-Making Rules on the Future EU, January 2008

2196 Antonis Adam, Margarita Katsimi and Thomas Moutos, Inequality and the Import Demand Function, January 2008

2197 Helmut Seitz, Democratic Participation and the Size of Regions: An Empirical Study Using Data on German Counties, January 2008

2198 Theresa Fahrenberger and Hans Gersbach, Minority Voting and Long-term Decisions, January 2008

2199 Chiara Dalle Nogare and Roberto Ricciuti, Term Limits: Do they really Affect Fiscal Policy Choices?, January 2008

2200 Andreas Bühn and Friedrich Schneider, MIMIC Models, Cointegration and Error Correction: An Application to the French Shadow Economy, January 2008

2201 Seppo Kari, Hanna Karikallio and Jukka Pirttilä, Anticipating Tax Change: Evidence from the Finnish Corporate Income Tax Reform of 2005, January 2008

2202 Walter Krämer and André Güttler, On Comparing the Accuracy of Default Predictions in the Rating Industry, January 2008

2203 Syed M. Ahsan and Panagiotis Tsigaris, The Efficiency Loss of Capital Income Taxation under Imperfect Loss Offset Provisions, January 2008

2204 P. Mohnen, F. C. Palm, S. Schim van der Loeff and A. Tiwari, Financial Constraints and other Obstacles: Are they a Threat to Innovation Activity?, January 2008

2205 Sascha O. Becker and Mathias Hoffmann, Equity Fund Ownership and the CrossRegional Diversification of Household Risk, January 2008

2206 Pedro R. D. Bom and Jenny E. Ligthart, How Productive is Public Capital? A MetaAnalysis, January 2008 
2207 Martin Werding, Ageing and Productivity Growth: Are there Macro-level Cohort Effects of Human Capital?, January 2008

2208 Frederick van der Ploeg and Steven Poelhekke, Globalization and the Rise of MegaCities in the Developing World, February 2008

2209 Sara Biancini, Regulating National Firms in a Common Market, February 2008

2210 Jin Cao and Gerhard Illing, Liquidity Shortages and Monetary Policy, February 2008

2211 Mathias Kifmann, The Design of Pension Pay Out Options when the Health Status during Retirement is Uncertain, February 2008

2212 Laszlo Goerke, Tax Overpayments, Tax Evasion, and Book-Tax Differences, February 2008

2213 Jun-ichi Itaya and Heinrich W. Ursprung, Price and Death, February 2008

2214 Valentina Bosetti, Carlo Carraro and Emanuele Massetti, Banking Permits: Economic Efficiency and Distributional Effects, February 2008

2215 Assar Lindbeck, Mårten Palme and Mats Persson, Social Interaction and Sickness Absence, February 2008

2216 Gary E. Bolton and Axel Ockenfels, The Limits of Trust in Economic Transactions Investigations of Perfect Reputation Systems, February 2008

2217 Hartmut Egger and Peter Egger, The Trade and Welfare Effects of Mergers in Space, February 2008

2218 Dorothee Crayen and Joerg Baten, Global Trends in Numeracy 1820-1949 and its Implications for Long-Run Growth, February 2008

2219 Stephane Dees, M. Hashem Pesaran, L. Vanessa Smith and Ron P. Smith, Identification of New Keynesian Phillips Curves from a Global Perspective, February 2008

2220 Jerome L. Stein, A Tale of Two Debt Crises: A Stochastic Optimal Control Analysis, February 2008

2221 Michael Melvin, Lukas Menkhoff and Maik Schmeling, Automating Exchange Rate Target Zones: Intervention via an Electronic Limit Order Book, February 2008

2222 Raymond Riezman and Ping Wang, Preference Bias and Outsourcing to Market: A Steady-State Analysis, February 2008

2223 Lars-Erik Borge and Jørn Rattsø, Young and Old Competing for Public Welfare Services, February 2008 
2224 Jose Apesteguia, Steffen Huck, Jörg Oechssler and Simon Weidenholzer, Imitation and the Evolution of Walrasian Behavior: Theoretically Fragile but Behaviorally Robust, February 2008

2225 Walter Krämer, Long Memory with Markov-Switching GARCH, February 2008

2226 António Afonso and Christophe Rault, What do we really Know about Fiscal Sustainability in the EU? A Panel Data Diagnostic, February 2008

2227 Sergey M. Kadochnikov and Igor M. Drapkin, Market Structure, Technological Gap and Vertical Linkage Effects from Foreign Direct Investment, February 2008

2228 Guglielmo Maria Caporale, Davide Ciferri and Alessandro Girardi, Fiscal Shocks and Real Exchange Rate Dynamics: Some Evidence for Latin America, February 2008

2229 Scott Alan Carson, Geography and Insolation in $19^{\text {th }}$ Century US African-American and White Statures, February 2008

2230 Wolfgang Buchholz and Jan Schumacher, Discounting and Welfare Analysis Over Time: Choosing the $\eta$, February 2008

2231 M. Hashem Pesaran, Christoph Schleicher and Paolo Zaffaroni, Model Averaging in Risk Management with an Application to Futures Markets, February 2008

2232 Wilhelm Kohler, Offshoring: Why Do Stories Differ?, February 2008

2233 Stefan Bach, Giacomo Corneo and Viktor Steiner, Effective Taxation of Top Incomes in Germany, 1992-2002, February 2008

2234 Robert S. Chirinko, $\sigma$ : The Long And Short Of It, February 2008

2235 Volker Grossmann and Holger Strulik, Should Continued Family Firms Face Lower Taxes than other Estates?, February 2008

2236 Guido Tabellini, The Scope of Cooperation: Values and Incentives, February 2008

2237 Heinrich W. Ursprung and Christian Wiermann, Reputation, Price, and Death: An Empirical Analysis of Art Price Formation, March 2008

2238 Hans Fehr and Christian Habermann, Private Retirement Savings in Germany: The Structure of Tax Incentives and Annuitization, March 2008

2239 Joseph Francois and Ian Wooton, Market Structure and Market Access, March 2008

2240 Hiroyuki Kasahara and Beverly Lapham, Productivity and the Decision to Import and Export: Theory and Evidence, March 2008

2241 Gary E. Bolton and Axel Ockenfels, Does Laboratory Trading Mirror Behavior in Real World Markets? Fair Bargaining and Competitive Bidding on EBay, March 2008 
2242 Atsushi Oshima, B. Ravikumar and Raymond Riezman, Entrepreneurship, Organization Capital and the Evolution of the Firm, March 2008

2243 Walter Krämer and Sebastian Schich, Large-Scale Disasters and the Insurance Industry, March 2008

2244 Leif Danziger, Adjustment Costs, Inventories and Output, March 2008

2245 Anne van Aaken, Lars P. Feld and Stefan Voigt, Power over Prosecutors Corrupts Politicians: Cross Country Evidence Using a New Indicator, March 2008

2246 Hans-Christian Heinemeyer, Max-Stephan Schulze and Nikolaus Wolf, Endogenous Borders? The Effects of New Borders on Trade in Central Europe 1885-1933, March 2008

2247 Johannes Becker and Clemens Fuest, Tax Competition - Greenfield Investment versus Mergers and Acquisitions, March 2008

2248 Giorgio Bellettini and Hubert Kempf, Why not in your Backyard? On the Location and Size of a Public Facility, March 2008

2249 Jose Luis Evia, Roberto Laserna and Stergios Skaperdas, Socio-Political Conflict and Economic Performance in Bolivia, March 2008

2250 Bas Jacobs and A. Lans Bovenberg, Optimal Taxation of Human Capital and the Earnings Function, March 2008

2251 Jan-Egbert Sturm and Timo Wollmershäuser, The Stress of Having a Single Monetary Policy in Europe, March 2008

2252 Guido Schwerdt, Labor Turnover before Plant Closure: 'Leaving the Sinking Ship' vs. 'Captain Throwing Ballast Overboard', March 2008

2253 Keith E. Maskus and Shuichiro Nishioka, Development-Related Biases in Factor Productivities and the HOV Model of Trade, March 2008

2254 Jeremy Edwards and Sheilagh Ogilvie, Contract Enforcement, Institutions and Social Capital: the Maghribi Traders Reappraised, March 2008

2255 Imed Drine and Christophe Rault, Purchasing Power Parity for Developing and Developed Countries. What can we Learn from Non-Stationary Panel Data Models?, March 2008

2256 Scott Alan Carson, Health, Wealth and Inequality: a Contribution to the Debate about the Relationship between Inequality and Health, March 2008 